\author{
A.R. Yeshkeyev* \\ E.A. Buketov Karaganda University, Karaganda \\ (E-mail: modth1705@mail.ru)
}

\title{
Method of the rheostat for studying properties of fragments of theoretical sets
}

\begin{abstract}
In this article discusses the model-theoretical properties of fragments of theoretical sets and the rheostat method. These two concepts: theoretical set and rheostat are new. The study of this topic in the framework of the study of Jonsson theories, the Jonsson spectrum, classes of existentially closed models of such fragments is a new promising class of problems and their solution is closely related to many problems that once defined the classical problems of model theory. The purpose of this article is to determine the rheostat of the transition from complete theory to Jonsson theory, which will be consistent with the corresponding concepts for any $\alpha$ and any $\alpha$-Jonsson theory. For this we define a theoretical set. On the basis of research by the author formulated a model-theoretical definition of the concept of a rheostat in the transition from complete theories to $\varphi(x)$-theoretically convex Jonsson sets. Also was formulated an application of $h$-syntactic similarity to $\alpha$-Jonsson theories.
\end{abstract}

Keywords: Jonsson theory, Jonsson spectrum, Jonsson set, theoretical set, fragment, rheostat.

This article is devoted to the study of model-theoretical properties of fragments [1-3] of theoretical sets. The concept of a theoretical set is defined as a special case of a Jonsson set [1]. In order to define a theoretical set, we take a fixed Jonsson set [4] and then we apply the universal quantifier for all free variables from existential formula which defined this set. And received universal-existential sentence should be satisfy for demand of Jonsson theory, i.e. to be Jonsson theory. It is clear that we can define in such way just finitely axiomatizable Jonsson theories. We will also consider the rheostat method and give a model-theoretical definition of the concept of a rheostat. Since both concepts: theoretical set and rheostat are new, we consider that the study of this topic in the framework of the study of Jonsson theories [2, 5, 6, 7], the Jonsson spectrum [5], classes of existentially closed models [5] of such fragments represents from itself a new promising class of problems and their solution is closely related to many problems that defined in their time the classical problems of Model Theory [8, 9].

Until now, the study of Jonsson theories and their classes of models [6, 10] was a complex of modeltheoretic problems, the formulation of which was due to adaptations of the conceptual apparatus and related content from the arsenal of the Model Theory course for the study of complete theories. It is clearly seen from the definition of Jonsson theory that these theories are, generally speaking, incomplete. Therefore, the direct transfer of results on complete theories to the field of study of Jonsson theories is not a simple and easy thing. Until now, we have used the so-called semantic method in solving problems related to the study of Jonsson theories. The essence of this method is to translate the elementary properties of the first order to the theory itself, while adapting the model-theoretical properties inherent for the center of this theory.

Let us consider in more detail on the need to study the above two new concepts: a theoretical set and a rheostat. Research of the definable subsets of the semantic model of a fixed Jonsson theory allows one to transfer many of the central ideas of modern methods of studying complete theories and their classes of models to the field of studying Jonsson theories and their classes of existentially closed models. These methods include, first of all, the methods of the so-called geometric stability [11, 12]. At the same time, it should be noted the outstanding contribution to the development of this direction

\footnotetext{
${ }^{*}$ Corresponding author.

E-mail: modth1705@mail.ru
} 
of modern Model Theory by the results of E. Hrushovski [13, 14], as well as the works of B. Zilber $[15,16]$. The concept of a Jonsson set allows us to consider issues related to geometric stability in the framework of the study of Jonsson theories and their classes of existentially closed models.

In this work, we want to focus our attention on the adaptation of problems from work [8,9] in the framework of studying the concepts of Jonsson rheostat and theoretical set. The concept of a rheostat arose in physics as a technical means for the study of such properties as current strength, voltage and resistance. Drawing an analogy with this technical means, we consider the classical modeltheoretical concepts from the technical and conceptual apparatus for the study of complete theories, we will adapt and investigate the corresponding model-theoretical concepts for the study of Jonsson theories. It is clear that a concept from the arsenal of complete theories is transformed in a certain way when translated into the Jonsson theory. And at the same time, we want to interpret the difference in the transformation of the concept by some mathematical property. Conditionally, a certain imaginary rheostat is responsible for the transformation, and therefore a necessary mathematical property that will characterize the transition from a concept in a complete theory to a concept in a Jonsson theory, and, accordingly, describe this transition in a syntactic or semantic way, and in what follows we will call this mathematical property the corresponding rheostat.

To formulate the main results, we will need some definitions and model-theoretical properties of these concepts. Those results that will not be determined can be extracted from the following works $[6,17,18,19,20,21]$.

By $\Pi_{n}$ we denote the set of all formulas in the language $L$ of the form $\forall \exists \ldots \varphi$ ((i.e., formulas with $n$ variables quantifiers starting with $\forall), \Sigma_{n}=\left\{\varphi: \neg \varphi \in \Pi_{n}\right\}, \nabla_{n}=\Pi_{n} \cup \Sigma_{n}$. Then

$$
\Pi_{\omega}=\Sigma_{\omega}=\nabla_{\omega}=\Pi_{\omega+1}=\Sigma_{\omega+1}=\Delta_{\omega+1}=\ldots=\bigcup_{n<\omega} \nabla_{n}
$$

Definition 1 [10]. Let $\Gamma \subset L$. Then:

1) $T \in \Gamma C_{\Delta}$ means that $T \cap \Gamma \vdash \varphi$ for all $\varphi \in T$;

2) if $B \subseteq|\mathfrak{A}|$, then $T h_{\Gamma}(\mathfrak{A}, B)$ denotes the set of all $\Gamma$-sentences in $L_{B}$, that are true in $\mathfrak{A}$;

3) the mapping $f: \mathfrak{A} \rightarrow \mathfrak{B}$ is called a $\Gamma$-embedding if for any $\bar{a} \in \mathfrak{A}$ and $\varphi(\bar{x}) \in \Gamma$ in $\mathfrak{A} \models \varphi(\bar{a})$ follows $\mathfrak{B}=\varphi(f(\bar{a}))$;

4) if $\mathfrak{A} \subseteq \mathfrak{B}$, then $\mathfrak{A} \subseteq \Gamma \mathfrak{B}$ means that $T h_{\Gamma}(\mathfrak{A},|\mathfrak{A}|) \subseteq T h_{\Gamma}(\mathfrak{B},|\mathfrak{A}|)$;

5) a sequence of models $\mathfrak{A}_{i}, i<\beta$, is called a $\Gamma$-chain if $\mathfrak{A}_{i} \subseteq_{\Gamma} \mathfrak{A}_{j}$ for $i<j<\beta$.

Lemma 1 [10]. The mapping $f: \mathfrak{A} \rightarrow \mathfrak{B}$ is a $\Pi_{\alpha}$-embedding if and only if it is a $\Sigma_{\alpha+1}$-embedding. Definition 2 [10].

1 . The theory $T$ is stable under the union of $\Pi_{\alpha}$-chains (or $\alpha$-inductive), if the union of any $\Pi_{\alpha}$-chain of models of $T$ is again a model of $T$.

2. The theory $T$ has the property of $\alpha$-joint embedding ( $\alpha$-JEP), if for any $\mathfrak{A}, \mathfrak{B} \models T$ there are $\mathfrak{M} \models T$ and $\Pi_{\alpha}$-embeddings $f: \mathfrak{A} \rightarrow \mathfrak{M}$ and $g: \mathfrak{B} \rightarrow \mathfrak{M}$.

3. The theory $T$ has the property of $\alpha$-amalgamation $\left(\alpha\right.$-AP), if for any $\mathfrak{A}, \mathfrak{B}_{1}, \mathfrak{B}_{2} \models T$ and $\Pi_{\alpha^{-}}$ embeddings $f_{1}: \mathfrak{A} \rightarrow \mathfrak{B}_{1}$ and $f_{2}: \mathfrak{A} \rightarrow \mathfrak{B}_{2}$ there are $\mathfrak{M} \models T$ и $\Pi_{\alpha}$-embeddings $g_{1}: \mathfrak{B}_{1} \rightarrow \mathfrak{M}$ and $g_{2}: \mathfrak{B}_{2} \rightarrow \mathfrak{M}$ such that $g_{1} \circ f_{1}=g_{2} \circ f_{2}$.

Definition 3 [10]. A theory $T$ is called $\alpha$-Jonsson theory, if

1) $T$ has an infinite models;

2) $T$ is $\alpha$-inductive;

3) $T$ has the $\alpha$-JEP;

4) $T$ has the $\alpha$-AP.

Lemma $2[10]$. 1. The theory $T$ is complete if and only if $T$ is $\omega$-Jonsson.

2. The theory $T$ is Jonsson in the sense if and only if $T$ is 0 -Jonsson.

Proposition 3 [10]. The following conditions are equivalent:

1) $T$ has the $\alpha$-JEP; 
2) $T$ has the $\alpha$-JEP for countable models;

3) If $\bar{x} \cap \bar{y}=\emptyset, p(\bar{x})$ and $q(\bar{y})$ are an arbitrary sets $\Sigma_{\alpha+1}$-formulas such that $T \cup p(\bar{x})$ and $T \cup q(\bar{y})$ are consistent, then $T \cup p(\bar{x}) \cup q(\bar{y})$ is consistent.

Proposition 4 [10]. The following conditions are equivalent:

1) $T$ has the $\alpha$-AP;

2) $T$ has the $\alpha$-AP for countable models;

3) If $p(\bar{x})$ and $q(\bar{x})$ are sets of $\Sigma_{\alpha+1^{-}}$formulas such that

$$
\begin{gathered}
T \cup p(\bar{x}), T \cup q(\bar{x}), \\
T \cup\left\{\neg \varphi(\bar{x}): \varphi(\bar{x}) \in \Sigma_{\alpha+1}, \varphi(\bar{x}) \notin p(\bar{x}) \cap q(\bar{x})\right\}
\end{gathered}
$$

are consistent sets, then the set $T \cup p(\bar{x}) \cup q(\bar{x})$ is consistent;

4) for any $\mathfrak{A} \models T$ and $\bar{a} \in \mathfrak{A}$ the set $T h_{\Sigma_{\alpha+1}}(\mathfrak{A}, \bar{a})$ is contained in the only maximal consistent with $T$ set of $\Sigma_{\alpha+1^{-}}$sentences of the language $L(\bar{a})$.

Proposition 5 [10]. The following conditions are equivalent:

1) $T \in \Pi_{\alpha+2} C_{\alpha}$;

2) the theory $T$ is $\alpha$-inductive.

Proposition 6 [10]. The property of a theory to be or not to be $\alpha$-Jonsson is absolute, i.e. does not depend on complementary to ZF axioms of set theory.

Proposition 7 [10]. The following conditions are equivalent:

1) $T \in \Pi_{\alpha+1} C_{\Delta}$;

2) If $\mathfrak{B}=T$ and $\mathfrak{A} \subseteq \Pi_{\alpha} \mathfrak{B}$, then $\mathfrak{A}=T$.

Proposition 8 [10]. The following conditions are equivalent:

1) $T \in \Sigma_{\alpha+1} C_{\Delta}$

2) If $\mathfrak{A} \models T$ and $\mathfrak{A} \subseteq \Pi_{\alpha} \mathfrak{B}$, then $\mathfrak{B}=T$.

Proposition 9 [10]. The following conditions are equivalent:

1) $T \in \nabla_{\alpha+1} C_{\Delta}$

2) If $\mathfrak{A}, \mathfrak{B}=T$ and $\mathfrak{A} \subseteq \complement_{\Pi_{\alpha}} \mathfrak{M} \subseteq \complement_{\Pi_{\alpha}} \mathfrak{B}$, then $\mathfrak{M}=T$.

Definition 4 [10]. Let $\alpha \leq \omega$.

1. An alternative chain over $\mathfrak{A} \subseteq \mathfrak{B}$ is a sequence of models $\mathfrak{A} \subseteq \mathfrak{B} \subseteq \mathfrak{M}_{0} \subseteq \mathfrak{M}_{1} \subseteq \ldots \subseteq \mathfrak{M}_{\beta} \subseteq$ $\ldots, \beta<\alpha$, satisfying the relations

(a) $\mathfrak{A} \preceq \mathfrak{M}_{0} \preceq \mathfrak{M}_{2} \preceq \ldots \preceq \mathfrak{M}_{2 i} \preceq \ldots, 2 i<\alpha$;

(b) $\mathfrak{A} \preceq \mathfrak{M}_{1} \preceq \mathfrak{M}_{3} \preceq \ldots \preceq \mathfrak{M}_{2 i+1} \preceq \ldots, 2 i+1<\alpha$;

2. A theory $T$ is called $\alpha$-alternative if for any $\mathfrak{A}, \mathfrak{B} \models T$ the equivalence $\mathfrak{A} \preceq \mathfrak{B} \Leftrightarrow(\mathfrak{A} \subseteq \mathfrak{B}$ and there is an alternative $\alpha$-chain over $\mathfrak{A} \subseteq \mathfrak{B}$ ).

Proposition 10 [10]. The following conditions are equivalent:

1) for any formula $\varphi(x) \in L$ there exists a $\Sigma_{\alpha+1}$-formula $\psi(x)$ such that $T \models \varphi(x) \leftrightarrow \psi(x)$;

2) for any formula $\varphi(x) \in L$ there exists a $\Pi_{\alpha+1}$-formula $\theta(x)$ such that $T=\varphi(x) \leftrightarrow \theta(x)$;

3) the theory $T$ is the $\alpha$-model complete;

4) the theory $T$ is the $\alpha$-alternative;

5) for any $\mathfrak{A}, \mathfrak{B}=T$ the relation holds

$$
\mathfrak{A} \subseteq \Pi_{\alpha} \mathfrak{B} \Leftrightarrow \mathfrak{A} \preceq \mathfrak{B} \Leftrightarrow \mathfrak{A} \subseteq \Sigma_{\alpha+1} \mathfrak{B}
$$

Proposition 11 [10]. The following conditions are equivalent:

1 ) in the $T$ theory, any formula is equivalent to a Boolean combination of $\nabla_{\alpha}$-formulas;

2) for any $\mathfrak{A} \models T$ and $\bar{a} \in \mathfrak{A}$ theory $T \cup T h_{\nabla_{\alpha}}(\mathfrak{A}, \bar{a})$ is complete;

3) (for the complete theory $T$ ) if $\mathfrak{A}$ is a saturated model of $T$ and $\bar{a} \in \mathfrak{A}$, then the theory $T \cup T h_{\nabla_{\alpha}}(\mathfrak{A}, \bar{a})$ is complete. 
Definition 5 [10]. The $\alpha$-Jonsson theory $T$ is called a perfect if $\mathfrak{G}_{T}$ is a saturated model $\operatorname{Th}\left(\mathfrak{G}_{T}\right)\left(=T^{*}\right)$.

Proposition 12 [10]. For the $\alpha$-Jonsson theory $T$ the following conditions are equivalent:

1) the theory $T$ is perfect;

2) $T^{*}$ is the $\alpha$-model completion (that is, the $\mathcal{D}\left(T^{*}\right)$ is $\alpha$-model completion) of the theory $T$.

All of the above facts and definitions are directly related to the transition from a complete theory to a Jonsson theory. Using these facts and definitions from [10], we can notice that in the language of generalized Jonsson theories, it is possible to formulate the results from [8,9] in a unified language for the $\alpha$-Jonsson theory, which was considered in [10].

The purpose of this article is to determine the rheostat of the transition from complete theory to Jonsson theory, which will be consistent with the corresponding concepts for any $\alpha$ and any $\alpha$-Jonsson theory. For this we define a theoretical set.

Definition 6 . Let $T$ be some Jonsson theory, $C$ is the semantic model of the theory $T, X \subseteq C$.

A set $X$ is called theoretical set, if

1) $X$ is Jonsson set, and let $\varphi(\bar{x})$ be the formula that defines the set $X$;

2) $\varphi(\bar{x})=\exists \bar{y} \psi(\bar{x}, \bar{y})$ and let $\theta$ be the universal closure of the formula $\varphi(\bar{x})$, i.e. $\theta$ is the sentence $\forall x \exists \bar{y} \psi(x, \bar{y})$ defines some Jonsson theory.

It is easy to see from Definition 6 that $\theta$ can only be a finitely axiomatizable theory and belongs to the Jonsson spectrum $J S p(M)$, where $M=\operatorname{cl}(X)$ and $M \in E_{T}$. It can be seen that $\forall \Delta \in J S p(M)$, if $\Delta$ is a finitely axiomatizable theory, then we can consider sentences $\theta^{\prime}$ such that $\theta^{\prime}$ defines a Jonsson theory $\Delta$. If we eliminate the universality quantifier in $\theta^{\prime}$, then we get formula, which defines a theoretical set that will be a subset of $M$. Thus, all the finitely axiomatizable Jonsson theories from $J S p(M)$ will be define uniquely some theoretical subset in the model $M$.

Definition \%. We will say that an existentially closed model $M$ is convex (strongly convex) if its Kaiser hull $\left(T h_{\forall \exists}(M)\right)$ is a convex (strongly convex) theory.

Definition 8 . We will say that an existentially closed model $M$ is $\varphi(x)$-convex if it is convex and

1) $\varphi(x)$ defines a Jonsson set in the model $M$;

2) if for all substructures $\mathfrak{A}_{i}$ of the model $M, \cap \mathfrak{A}_{i}$ contains $\varphi(M)$, given that this intersection is not empty.

If this intersection is never empty and the model $M$ is a strongly convex, then the model $M$ is called the $\varphi(x)$-strongly convex.

If the semantic model $C$ of a Jonsson theory $T$ is $\varphi(x)$-convex (strongly convex), then the theory $T$ itself is correspondingly the same. Note that the classical definition of convexity [3;41; Def. 2] of the theory coincides with this definition if we omit the prefix $\varphi(x)$.

Definition 9. A model $M \in E_{T}$ is called $\varphi(x)$-theoretical convex (strongly convex) if this model $\varphi(x)$-convex (strongly convex) and $\varphi(x)$ defines a theoretical set.

The following definition provides a generalization of the concept of the syntactic similarity of Jonsson theories.

Definition 10. Let $T_{1}$ and $T_{2}$ are an arbitrary Jonsson theories. We say, that $T_{1}$ and $T_{2}$ are the $h$-syntactically similar, where $h$ is map $h: E\left(T_{1}\right) \longrightarrow E\left(T_{2}\right)$ such that

1) restriction $h$ to $E_{n}\left(T_{1}\right)$ is homomorphism of lattices $E_{n}\left(T_{1}\right)$ and $E_{n}\left(T_{2}\right), n<\omega$;

2) $h\left(\exists v_{n+1} \varphi\right)=\exists v_{n+1} h(\varphi), \varphi \in E_{n+1}(T), n<\omega$;

3) $h\left(v_{1}=v_{2}\right)=\left(v_{1}=v_{2}\right)$.

If the kernel $\operatorname{Ker}(h)$ of this homomorphism is trivial, then we obtain a definition of the syntactic similarity of two Jonsson theories [22; 167; def. 10].

We are now ready to give a model-theoretical definition of the concept of a rheostat in the transition from complete theories to $\varphi(x)$-theoretically convex Jonsson sets.

Definition 11. Let $T$ be some Jonsson theory, $C$ is the semantical model of the theory $T, X \subseteq C$, $X$ is the theoretical set. $\varphi(C)=X, \varphi(x) \in L$. 
If the universal closure $\varphi(x)$ will be the Jonsson theory and the Kaiser hull $M^{0}=T h_{\forall \exists}(M)$, $M \in E_{T}$, where $M=\operatorname{cl}(\varphi(C))$, then we will say that $\varphi(x)$ is a rheostat if exists $h$-syntactic similarity between theories $T$ and $T h_{\forall \exists}(M)$.

The next result is an application of $h$-syntactic similarity to $\alpha$-Jonsson theories.

Theorem. Let $T_{1}, T_{2}$ be $\varphi(x)$-convex (strongly convex) complete for existential sentences perfect $\alpha$-Jonsson theories. Then the following conditions are equivalent:

1) $T_{1}, T_{2}$ are the $h$-syntactically similar and the kernel $\operatorname{Ker}(h)$ is trivial;

2) $T_{1}^{*}, T_{2}^{*}$ are the syntactically similar in the sense of [23] and $\alpha=\omega$;

3) $T h_{\forall \exists}\left(M_{1}\right)=T_{1}^{*}, T h_{\forall \exists}\left(M_{2}\right)=T_{2}^{*}$, where $C_{1}$ is a semantic model of the theory $T_{1}, C_{2}$ is a semantic model of the theory $T_{2}, \operatorname{cl}\left(\varphi\left(C_{1}\right)\right)=M_{1}, \operatorname{cl}\left(\varphi\left(C_{2}\right)\right)=M_{2}$.

Proof. The proof follows from Theorem 2.7.1 [6;182] and from Definition 11.

Consequence. All Propositions 3-12 are true for the corresponding $\varphi(x)$-rheostat and the ordinal $\alpha$, which defines the $\alpha$-Jonsson theory. Moreover, there is an $h$-syntactic similarity between the $\alpha$-Jonsson theory and the corresponding Kaiser hull of the fragment of the theoretical set defined by the formula $\varphi(x)$ and the corresponding $\alpha$-Jonsson theory.

\section{References}

1 Yeshkeyev A.R. Strongly minimal Jonsson sets and their properties / A.R. Yeshkeyev // Bulletin of the Karaganda University - Mathematics. - 2015. - Vol. 80. - No. 4. -P. 47-51.

2 Yeshkeyev A.R. On lattice of existential formulas for fragment of Jonsson set / A.R. Yeshkeyev, O.I. Ulbrikht // Bulletin of the Karaganda University - Mathematics. - 2015. - Vol. 79. No. 3. -P. 33-39.

3 Yeshkeyev A.R. Companions of the fragments in the Jonsson enrichment / A.R. Yeshkeyev // Bulletin of the Karaganda University - Mathematics. - 2017. - Vol. 85. - No. 1. - P. 41-45. DOI: $10.31489 / 2017 \mathrm{M} 1 / 41-45$

4 Yeshkeyev A.R. The atomic definable subsets of semantic model /A.R. Yeshkeyev, N.M. Mussina, A.K. Issayeva // Bulletin of the Karaganda University - Mathematics. - 2019. - Vol. 94. - No. 2. - P. 84-91. DOI 10.31489/2019M2/84-91

5 Ешкеев A.P. JSp-косемантичность $R$-модулей [Электронный ресурс] / A.P. Ешкеев, О.И. Ульбрихт // Siberian electronics mathematical report. - 2019. - Вып. 16. - C. 1233-1244. Режим доступа: http://semr.math. nsc.ru. DOI: 10.33048/semi.2019.16.084

6 Ешкеев А.Р. Йонсоновские теории и их классы моделей: моногр. / А.Р. Ешкеев, М.Т. Касыметова. - Караганда: Изд-во КарГУ, 2016. - 370 с.

7 Yeshkeyev A.R. The Properties of Similarity for Jonsson's Theories and Their Models / A.R. Yeshkeyev // Bulletin of the Karaganda University - Mathematics. - 2015. - Vol. 80. - No. 4. - P. 52-59.

8 Vaught R. Denumerable models of complete theories in Infinitistic Methode / R. Vaught // Pergamon. London, 1961. p. 303-321.

9 Baldwin J.T. Algebraically prime models/ J.T.Baldwin, D.W. Kueker// Ann. Math. Logic. 1981, 20, p. 289-330.

10 Мустафин Т.Г. Обобщенные условия Йонсона и описание обобщенно-йонсоновских теорий булевых алгебр / Т.Г. Мустафин // Матем. тр. - 1998. - Т. 1. - № 1. - С. 135-197.

11 Pillay A. Geometric Stability Theory. /A. Pillay // Oxford University Press - 1996.

12 Marker D. Model theory : an introduction. /D. Marker// Springer-Verlag New York, Inc. - 2002.

13 Hrushovski E. A new strongly minimal set/E. Hrushovski // Ann. Pure and Appl. Logic.-1993.V. 62. - P. 147-166. 
14 Hrushovski E. The Mordell-Lang conjecture for function fields / E. Hrushovski // J. Amer. Math. Soc. - 1996. - V.9. - No.3. - P. 667-690.

15 Zilber B.I. Zariski Geometries. Geometry from the Logician's Point of View. / B.I. Zilber // Cambridge University Press, 2010.

16 Hrushovski E., Zilber B.I. Zariski geometries / E. Hrushovski, B.I. Zilber // Bulletin of the American Math. Soc. - 1993. - V.28. - P. 315-324.

17 Ешкеев А.Р. $J S p$-косемантичность и $J S B$-свойство абелевых групп [Электронный ресурс] / A.P. Ешкеев, О.И. Ульбрихт // Siberian Electronic Mathematical Reports. - 2016. - Вып. 13. - C. 861-874. - Режим доступа: http://semr.math.nsc.ru.DOI: 10.17377/semi.2016.13.068

18 Yeshkeyev A.R. del-cl-atomic and prime sets / A.R. Yeshkeyev, A.K. Issayeva // Bulletin of the Karaganda University - Mathematics. - 2019. - Vol. 93. - No. 1. - P. 88-94. DOI: $10.31489 / 2019 \mathrm{M} 1 / 88-94$

19 Yeshkeyev A.R. The properties of central types with respect to enrichment by Jonsson set / A.R. Yeshkeyev // Bulletin of the Karaganda University - Mathematics. - 2017. - Vol. 85. No. 1. - P. 36-40. DOI: $10.31489 / 2017 \mathrm{M} 1 / 36-40$

20 Yeshkeyev A.R. The structure of lattices of positive existential formulae of (Delta - PJ)-theories / A.R. Yeshkeyev // ScienceAsia. - 2013. - Vol. 39. - No. 1. - P. 19-24.

21 Yeshkeyev A.R. Properties of hybrids of Jonsson theories/ A.R. Yeshkeyev, N. M. Mussina // Bulletin of the Karaganda University - Mathematics. - 2018. - Vol. 92. - No. 4. - P. 99-104. DOI: $10.31489 / 2018 \mathrm{M} 4 / 99-104$

22 Yeshkeyev A.R. Model-theoretical questions of the Jonsson spectrum /A.R. Yeshkeyev // Bulletin of the Karaganda University - Mathematics.-2020. - Vol. 98. - No.2. - P. 165-173. DOI: $10.31489 / 2020 \mathrm{M} 2 / 165-173$

23 Mustafin T.G. On similarities of complete theories / T.G. Mustafin // Logic Colloquium '90. Proceedings of the Annual European Summer Meeting of the Association for Symbolic Logic. Helsinki, 1990. - P. 259-265.

\title{
A.P. Ешкеев
}

\section{Теоретикалық жиындардың фрагменттерінің қасиеттерін зерттеу үшін реостат әдісі}

\begin{abstract}
Мақалада теоретикалық жиындардың фрагменттерінің модельді-теоретикалық қасиеттері және реостат әдісі қарастырылған. Бұл екі ұғым - теоретикалық жиын және реостат - жаңа. Йонсондық теориялар, йонсондық спектрді, осындай фрагменттердің экзистенциалды тұйық модельдерінің кластарының аясында осы тақырыпты зерттеу - бұл проблемалардың жаңа перспективалы класы және оларды шешу модельдер теориясының классикалық мәселелерін анықтаған көптеген сұрақтармен тығыз байланысты. Бұл жұмыстың мақсаты - кез келген $\alpha$ және $\alpha$-йонсондық теорияның ұғымдарына сәйкес келетін толық теориядан йонсондық теориясына өту реостатын анықтау. Ол үшін автор теоретикалық жиынды анықтады. Зерттеу негізінде ол толық теориялардан $\varphi(x)$-теоретикалық дөңес йонсондық жиындарға өту кезіндегі реостат ұғымының модельді-теоретикалық анықтамасын, сонымен қатар $h$-синтактикалық ұқсастығын $\alpha$-йонсондық теорияларына қолдануды тұжырымдады.
\end{abstract}

Kiлm сөздер: йонсондық теория, йонсондық спектр, йонсондық жиын, теоретикалық жиын, фрагмент, реостат. 
А.Р. Ешкеев

\title{
Метод реостата для изучения свойств фрагментов теоретических множеств
}

\begin{abstract}
В статье рассмотрены теоретико-модельные свойства фрагментов теоретических множеств и метод реостата. Эти два понятия - теоретическое множество и реостат - являются новыми. Изучение данной тематики в рамках йонсоновских теорий, йонсоновского спектра, классов экзистенциально замкнутых моделей представляет из себя новый перспективный класс задач, и решение их тесно связано со многими проблемами, которые определяли в свое время классические проблемы теории моделей. Цель настоящей работы - определить реостат перехода от полной теории к йонсоновской теории, который будет согласован соответствующими понятиями для любого $\alpha$ и любой $\alpha$-йонсоновской теории. Для этого автором определено теоретическое множество. На основе проведенного исследования сформулированы теоретико-модельное определение понятия реостата при переходе от полных теорий к $\varphi(x)$-теоретически выпуклым йонсоновским множествам, а также приложение $h$-синтаксического подобия к $\alpha$-йонсоновским теориям.
\end{abstract}

Ключевые слова: йонсоновская теория, йононовский спектр, йонсоновское множество, теоретическое множество, фрагмент, реостат.

\section{References}

1 Yeshkeyev, A.R. (2015). Strongly minimal Jonsson sets and their properties. Bulletin of the Karaganda University - Mathematics, Vol. 80, 4, 47-51.

2 Yeshkeyev, A.R. \& Ulbrikht O.I. (2015). On lattice of existential formulas for fragment of Jonsson set. Bulletin of the Karaganda University - Mathematics, Vol. 79, 3, 33-39.

3 Yeshkeyev, A.R. (2017). Companions of the fragments in the Jonsson enrichment. Bulletin of the Karaganda University - Mathematics, Vol. 85,1, 41-45. DOI: 10.31489/2017M1/41-45

4 Yeshkeyev, A.R., Issayeva, A.K., \& Mussina, N.M. (2019). The atomic definable subsets of semantic model. Bulletin of the Karaganda University - Mathematics, Vol. 94, 2, 84-91. DOI 10.31489/2019M2/84-91

5 Yeshkeyev, A.R. \& Ulbrikht, O.I. (2019). JSp-kosemantichnost R-modulei /JSp-cosemanticness of $R$-modules]. Siberian Electronic Mathematical Reports. Retrieved from http://semr.math.nsc.ru. [in Russian]. DOI: 10.33048/semi.2019.16.084

6 Yeshkeyev, A.R. \& Kassymetova, M.T. (2016). Yonsonovskie teorii i ikh klassy modelei /Jonsson theories and their classes of models]. Karaganda: Izdatelstvo KarHU [in Russian].

7 Yeshkeyev, A.R. (2015). The Properties of Similarity for Jonsson's Theories and Their Models. Bulletin of the Karaganda University - Mathematics, Vol. 80, 4, 52-59.

8 Vaught, R. (1961). Denumerable models of complete theories in Infinitistic Methode. Pergamon. London.

9 Baldwin, J.T. \& Kueker, D.W. (1981). Algebraically prime models. Ann. Math. Logic., 20, 289330.

10 Mustafin, T.G. (1998). Obobshchennye uslovia Yonsona i opisaniie obobshchenno-ionsonovskikh teorii bulevykh alhebr [Generalized Jonsson's conditions and a description of generalized Jonsson theories of Boolean algebras]. Matematicheskie trudy-Mathematical Works, Vol. 1, 1, 135-197 [in Russian].

11 Pillay, A. (1996). Geometric Stability Theory. Oxford University Press.

12 Marker, D. (2002). Model theory: an introduction. Springer-Verlag New York, Inc.

13 Hrushovski, E. (1993). A new strongly minimal set Ann. Pure and Appl. Logic, V. 62, 147-166. 
14 Hrushovski, E. (1996). The Mordell-Lang conjecture for function fields. J. Amer. Math. Soc., Vol. 9, 3, 667-690.

15 Zilber, B.I. (2010). Zariski Geometries. Geometry from the Logician's Point of View. Cambridge University Press.

16 Hrushovski, E. \& Zilber, B.I. (1993). Zariski geometries. Bulletin of the American Math. Soc., V. 28, 315-324.

17 Yeshkeyev, A.R. \& Ulbrikht, O.I. (2016). JSp-kosemantichnost i JSB-svoistvo abelevykh hrupp [JSp-cosemanticness and JSB property of Abelian groups]. Siberian Electronic Mathematical Reports. Retrieved from http://semr.math.nsc.ru. [in Russian]. DOI: 10.17377/semi.2016.13.068

18 Yeshkeyev, A.R. \& Issayeva, A.K. (2019). del-cl-atomic and prime sets. Bulletin of the Karaganda University - Mathematics, Vol. 93, 1, 88-94. DOI: 10.31489/2019M1/88-94

19 Yeshkeyev, A.R. (2017). The properties of central types with respect to enrichment by Jonsson set. Bulletin of the Karaganda University - Mathematics, Vol. 85, 1, 36-40. DOI: 10.31489/2017M1/3640

20 Yeshkeyev, A.R. (2013). The structure of lattices of positive existential formulae of (Delta PJ)-theories. ScienceAsia, Vol. 39, 1, 19-24.

21 Yeshkeyev, A.R. \& Mussina, N.M. (2018). Properties of hybrids of Jonsson theories. Bulletin of the Karaganda University - Mathematics, Vol. 92, 4, 99-104. DOI: 10.31489/2018M4/99-104

22 Yeshkeyev, A.R. (2020). Model-theoretical questions of the Jonsson spectrum. Bulletin of the Karaganda University - Mathematics, Vol. 98, 2, 165-173. DOI: 10.31489/2020M2/165-173

23 Mustafin, T.G. (1990). On similarities of complete theories. Logic Colloquium '90. Proceedings of the Annual European Summer Meeting of the Association for Symbolic Logic. Helsinki. 